\title{
PENGGUNAAN VIDEO PEMBELAJARAN DALAM MENGEMBANGKAN MOTORIK KASAR ANAK USIA 4-6 TAHUN
}

\author{
Novi Nurlela ${ }^{1}$, Widya Astuti ${ }^{1}$, Zahrina Amelia ${ }^{1}$ \\ ${ }^{1}$ Program Studi Pendidikan Guru Pendidikan Anak Usia Dini, Fakultas Psikologi dan \\ Pendidikan, UniversitasAl Azhar Indonesia, Jalan Sisingamangaraja Kebayoran Baru, Jakarta \\ Selatan, 12110
}

Penulis untuk korespondensi/ E-mail: lelan2335@gmail.com

\begin{abstract}
Abstrak - Tujuan penelitian ini adalah untuk menggambarkan tentang video pembelajaran online yang digunakan dalam mengembangkan motorik kasar anak usia 4-6 tahun. Metode penelitian yang digunakan adalah kualitatif dengan teknik pengumpulan data menggunakan kuesioner hasil dari responden yang diteliti. Analisa data menggunakan analisis secara deskriptif. Jumlah responden dalam penelitian ini yaitu 21 orang tua yang memiliki anak usia 4-6 tahun di Kelurahan Bojong Menteng. Hasil penelitian menunjukkan bahwa video pembelajaran yang digunakan dalam mengembangkan motorik kasar anak usia 4-6 tahun di Kelurahan Bojong Menteng yaitu masih belum maksimal dikarenakan dalam beberapa jenis motorik kasar, komponennya belum terpenuhi semua. Jenis lokomotor yang belum tercapai yaitu gerakan memanjat, jenis non-lokomotor yang belum tercapai yaitu gerakan melompat ditempat, menekuk, meregang, mendorong, memutar, menggeleng, mengangguk, membungkuk, dan mengayunkan tangan, dan jenis manipulatif yang belum tercapai yaitu gerakan memukul, memantulkan, memutar tali, dan menangkap objek. Peran orang tua sangat penting untuk memantau dan terus melatih perkembangan motorik kasar anak.
\end{abstract}

Kata Kunci: Video Pembelajaran, Motorik Kasar

Abstract - The purpose of this study was to describe online learning videos used in developing gross motor skills for children aged 4-6 years. The research method used is qualitative with data collection techniques using questionnaires from the respondents studied. Data analysis used descriptive analysis. The number of respondents in this study were 21 parents who had children aged 4-6 years in Bojong Menteng Village. The results showed that the learning videos used in developing gross motor skills for children aged 4-6 years in Bojong Menteng Village were still not optimal because in some types of gross motor skills, all of the components had not been fulfilled. The types of locomotor movements that have not been achieved are climbing movements, non-locomotor types that have not been achieved, namely jumping in place, bending, stretching, pushing, twisting, shaking, nodding, bending, and swinging their hands, and manipulative types that have not been achieved are hitting, bouncing movements., twist the rope, and catch the object. The role of parents is very important to monitor and continue to train children's gross motor development.

Keywords: Learning video, gross motor skills 


\section{PENDAHULUAN}

$\mathrm{B}$ erita kasus Covid-19 telah tersebar keseluruh penjuru dunia, termasuk Indonesia. Kasus Covid-19 di Indonesia telah ada semenjak bulan Maret 2020, semua aktivitas terpaksa harus dirumahkan demi mencegahnya penyebaran virus secara luas. Aktivitas tersebut salah satu nya adalah pembelajaran. Pembelajaran harus dilakukan secara online merujuk kepada Surat Edaran No.3/2020 melalui Kementerian Pendidikan dan Kebudayaan yang melakukan semua upayanya dalam mengatur aturan pembelajaran online. Kebijakan ini tentunya membawa dampak bagi semua lembaga pendidikan, termasuk TK dan PAUD. Lembaga tersebut terpaksa harus melaksanakannya juga secara online. Hal ini membuat semua pendidik TK dan PAUD beserta orang tua khawatir terhadap pemenuhan aspekaspek perkembangan anak usia dini, khususnya anak usia 4-6 tahun. Hal ini dikarenakan pada enam tahun pertama anak mengalami pertumbuhan dan perkembangan yang sangat pesa, dengan tiga tahun awal lebih cepat dibandingkan nantinya (Nadhira, 2020). Salah satu aspek penting dalam perkembangan anak usia dini adalah perkembangan motorik kasar, dimana motorik kasar ini bisa kita lihat dalam pembelajaran biasanya dilakukan melalui kegiatan secara offline. Kini, semua harus dilaksanakan dengan pembelajaran online. Menurut Ayuni, dkk (2020), pembelajaran daring (dalam jaringan) atau online ialah bimbingan dalam kelas secara online agar mencapai arah pembelajaran secara daring. Pembelajaran ini bisa dilakukan kapan saja dan dimana saja. Pembelajaran ini juga mengharuskan orang tua mendampingi anak setiap saat ketika pembelajaran ini dimulai. Menurut Pohan (2020), pembelajaran daring dilakukan dengan menggunakan jaringan tanpa saling bertatap muka secara langsung. Bisa dilaksanakan kapan dan dimana saja asal memiliki koneksi internet yang stabil sehingga memudahkan proses pembelajaran secara daring.

Pembelajaran secara daring banyak digunakan dengan media video pembelajaran. Video pembelajaran merupakan media yang berpedoman pada kurikulum dengan pengembangan aplikasinya melalui prinsip-prinsip pembelajaran sehingga memudahkan peserta didik memahami materi pelajaran dengan mudah dan menarik. Video pembelajaran ini biasanya dikemas melalui peralatan VTR atau VCD player dan juga TV monitor. Video pembelajaran menampilkan berbagai jenis animasi, gambar, dan audio visual yang dapat menunjang fokus anak terhadap materi yang disampaikan guru dan membuat guru jauh lebih percaya diri dengan adanya hal ini (Taib \& Mahmudi, 2021). Tujuan dari video pembelajaran itu sendiri, menurut Riyana (2007: 6) adalah untuk menjelaskan dan memudahkan apa yang ingin disampaikan agar tidak terlalu verbalistis, mengatasi keterbatasan ruang, waktu dan daya indera anak-anak maupun instrukturnya, serta digunakan dengan tepat dan bervariasi sesuai kreatif dari masing-masing pembuat.

Adanya ketentuan baru dengan menggunakan video pembelajaran secara online akankah tetap bisa mengembangkan perkembangan motorik kasar untuk anak usia 4-6 tahun? Karena tentunya hal ini tidak mudah bisa dilakukan saat pembelajaran melalui video online. Pembelajaran melalui video online ini dianggap kurang efektif dan kurang baik diterapkan pada anak-anak, sebagaimana yang semua orang ketahui bahwa anak-anak usia dini khusunya usia 4-6 tahun merupakan usia-usia dimana mereka masih dalam tahap perkembangan dan pertumbuhan terutama pada motorik kasarnya. Perkembangan pada motorik kasar sangatlah penting bagi kehidupan anak usia 4-6 tahun agar bisa menjalankan aktivitas secara motorik dengan baik. Motorik kasar merupakan gerakan yang melibatkan otototot besar tubuh misalnya, melompat, berlari, melempar dan menangkap. Semua ini akan 
terbentuk dari bagaimana dan seberapa banyak anak melakukan aktivitas motorik kasar dalam kegiatan mainnya. Melihat secara garis besar bagaimana bentuk-bentuk perkembangan dari motorik kasar yang memerlukan sebuah aktivitas aktif dimana anak-anak harus banyak bersosilasisasi dan berinteraktif dengan guru, teman sebaya maupun dengan lingkungan sekitar.

Menurut Novitasari, dkk (2020) bahwa motorik kasar ialah dari kematangan anak sehingga kegiatan dikaitkan oleh sekujur badan anak. Sedangkan Hidayanti (2013) menyatakan motorik kasar ialah sejak masa kanak-kanak yang melibatkan otot-otot besar dalam setiap keterampilan kegiatannya sesuai kekuatan diri sendiri. Dapat kita amati untuk perkembangan ini melalui kegiatan sehari-hari anak yang menggunakan keterlibatan fisik seluruh tubuh karena perkembangan motorik kasar lebih dahulu dibandingkan dengan perkembangan motorik halus misalnya, ketika bayi didalam kandungan sudah mulai menendang-nendang perut ibu dan ibu akan mulai merasakan tendangan-tendangan tersebut.

Menurut hidayat (2017) kemampuan motorik terbagi atas beberapa bagian: (1) kemampuan lokomotor adalah suatu kemampuan yang dilakukan dengan menghasilkan perpindahan dari suatu tempat ke tempat lainnya misalnya berlari, melompat, berjalan, memanjat, berenang dan merangkak. Fungsi dari kemampuan lokomotor ini adalah untuk melatih kaki agar bisa melangkah dengan tepat dan benar, melatih kecepatan gerakannya dan agar kaki lebih siap terhadap rangsangan. (2) kemampuan non-lokomotor adalah kemampuan yang tidak mengubah posisi. Misalnya ketika anak loncat ditempat, jalan kaki ditempat, menggeleng, mengangguk, membungkuk, mengayunkan tangan, serta mendorong dan menarik. Fungsi dari kemampuan non-lokomotor agar tubuh tetap bergerak tetapi tidak mengubah posisi untuk melatih keseimbangan. (3) kemampuan manipulatif adalah kemampuan yang menggunakan alat dengan melibatkan kaki dan tangan. Misalnya gerakan melempar, memukul, memutar tali, memantulkan dan menggiring bola. Kemampuan jenis ini berfungsi untuk memperbaiki bentuk tubuh, kebugaran serta kesegaran jasmani. Keterampilan motorik kasar pada anak tentunya akan berbedabeda, namun ada beberapa unsur keterampilan yang harus ada dalam perkembangan motorik kasar, diantaranya: (1) kekuatan, yaitu akan menimbulkan suatu tenaga karena adanya keterampilan sekelompok otot tubuh. Contoh kegiatan yang memerlukan kekuatan yaitu, berlari, melompat, memanjat, melempar, dan mendorong; (2) koordinasi, yaitu adanya keterampilan dalam menyatukan beberapa sistem koordinasi dalam tubuh. Contoh kegiatanya yaitu, ketika anak melakukan aktivitas melempar tidak hanya kekuatan yang diperlukan, tetapi, adanya koordinasi seluruh bagian tubuh yang lainnya; (3) kecepatan, yaitu adanya keterampilan dalam melakukan suatu aktivitas dengan pemberian waktu; (4) keseimbangan, yaitu sebuah keterampilan tubuh untuk menyesuaikan posisi; (5) kelincahan, yaitu sebuah keterampilan untuk gerak cepat dalam berpindah posisi. Contoh kegiatan yang bisa dilakukan anak usia dini yaitu, bermain menjala ikan, dan bermain kucing dan tikus (Farida, 2016)

\section{METODE PENELITIAN}

Pendekatan yang digunakan dalam penelitian ini adalah pendekatan kualitatif. Hal ini dilakukan karena peneliti ingin mendapat gambaran yang jelas dan akurat mengenai materi atau fenomena yang diselidiki secara ilmiah. Sugiyono mengatakan bahwa, "Penelitian kualitatif (Qualitatif research) adalah suatu penelitian yang ditunjukkan untuk mendeskripsikan dan menganalisis fenomena, peristiwa, aktivitas sosial, sikap, kepercayaan, pesepsi, pemikiran orang secara individual maupun kelompok (Sugiono, 
2016). Dengan demikian penelitian ini dapat memberikan gambaran penggunaan video pembelajaran dalam mengembangkan motorik kasar anak usia 4-6 tahun.

\section{HASIL DAN PEMBAHASAN}

Berdasarkan hasil responden penelitian melalui media Google Form di wilayah Kelurahan Bojong Menteng, Kota Bekasi didapatkan yang mengisi data sebanyak 21 orang tua yang memiliki anak usia 4-6 tahun selama satu pekan penyebaran kuesioner, dapat disimpulkan bahwa
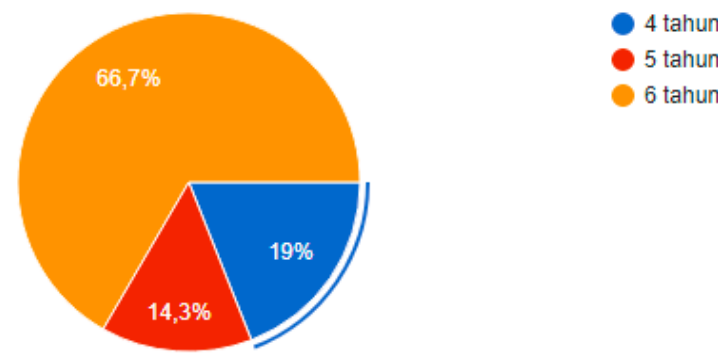

Gambar 1. Usia Anak

Dari 21 jawaban orang tua lebih mendominasi memiliki anak usia 6 tahun dibandingkan usia 4 dan 5 tahun yang hanya berjumlah sebanyak 33,3\%. Dapat disimpulkan pula dalam hal ini anak yang menjadi fokus subjek penelitian adalah anak berusia 6 tahun yang bisa dilihat perkembangan motorik kasarnya hasil dari adanya video pembelajaran.
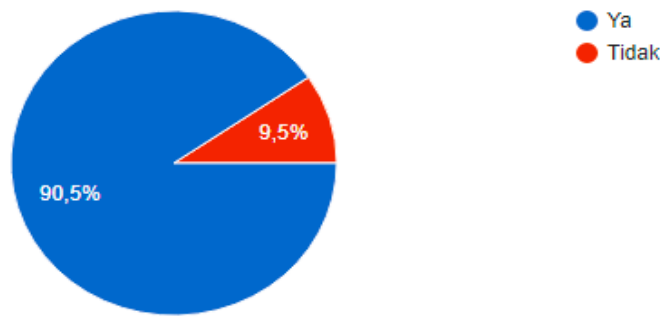

Gambar 2. Pengetahuan tentang video pembelajaran
Merujuk pada pertanyaan penelitian dalam kuisioner mengenai mencari informasi sebanyak apakah orang tua yang mengetahui mengenai video pembelajaran. Hasil dalam pertanyaan ini menyatakan bahwa sebanyak $90.5 \%$ orang tua telah mengetahui apa itu video pembelajaran, namun sebanyak $9,5 \%$ orang tua belum mengetahui video pembelajaran itu seperti apa.

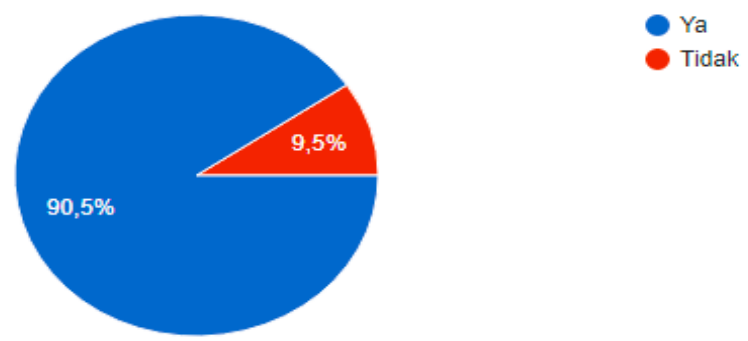

Gambar 3. Penggunaan video pembelajaran

Terkait pertanyaan selanjutnya, ternyata sebanyak $90,5 \%$ orang tua mengatakan bahwa video pembelajaran saat pandemi seperti ini sering digunakan, tetapi sebanyak $9,5 \%$ orang tua menjawab tidak sering digunakan.

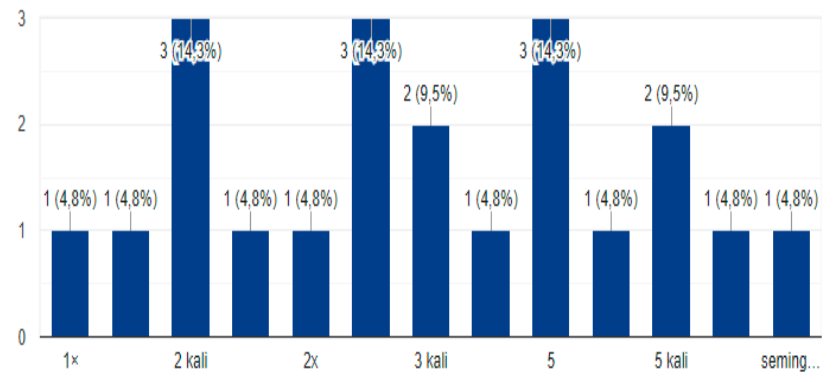

Gambar 4. Intensitas dalam 1 minggu menggunakan dan melihat video pembelajaran

Dari hasil data survey tersebut beberapa orang tua menyebutkan bahwa penggunaan video pembelajaran lebih dominan digunakan selama 2 dan 5 kali dalam seminggu dengan jumlah responden sebanyak $28,6 \%$. Sedangkan orang tua 
yang lain lebih banyak menjawab 3 kali dalam seminggu.

Apakah video pembelajaran ini efektif untuk menggantikan pembelajaran di dalam kelas secara langsung?

21 jawaban
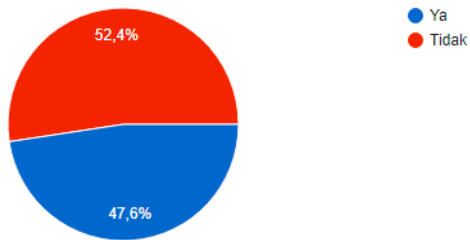

Gambaran Video Pembelajaran Online

Pertanyaan Ja alasannya?

21 jawaban

Anak menjadi lebih paham dengan materi pembelajaran yang disampaikan

la

Anak lebih faham

Anak kurang begitu paham

Karena lebih efektif bertatap muka

daripada nonton youtube

Karena tidak cepat dalam menangkap

pembelajaran

Suasana pandemi mengharuskan kita untuk belajar dirumah

Gambar 5. Efektifitas penggunaan video pembelajaran di kelas

Masa pandemi seperti ini banyak lembaga pendidikan yang menggunakan media video pembelajaran sebagai pemaparan materinya. Namun, terkait pertanyaan di atas orang tua lebih banyak yang mengatakan bahwa video pembelajaran ini tidak efektif untuk pembelajaran anak usia dini dengan dinyatakan dengan jumlah suara sebanyak $52.4 \%$. Alasan yang digunakan orang tua menilai bahwa video pembelajaran tidak efektif karena anak kurang paham terhadap materi yang disampaikan, anak tidak cepat dalam menangkap pembelajaran, anak tidak fokus dalam menonton video pembelajaran, anak menjadi kurang belajar mandiri, anak membutuhkan interaksi langsung dengan guru dan teman sebaya, dan anak menjadi lebih menyukai main ponsel dibandingkan belajar.

Sedangkan terkait respon orang tua sebanyak $47.6 \%$ yang menyatakan video pembelajaran ini efektif digunakan dalam pembelajaran dengan alasan karena menganggap bahwa anak menjadi lebih paham dengan materi yang disampaikan, suasana pandemi yang mengharuskan belajar dari rumah, anak cenderung pendiam sehingga lebih menyukai pembelajaran melalui online dan menggunakan ponsel, anak tertarik dengan video pembelajaran, video pembelajaran sangat berguna, dan dalam keadaan seperti ini video pembelajaran melalui online adalah pilihan yang tepat.

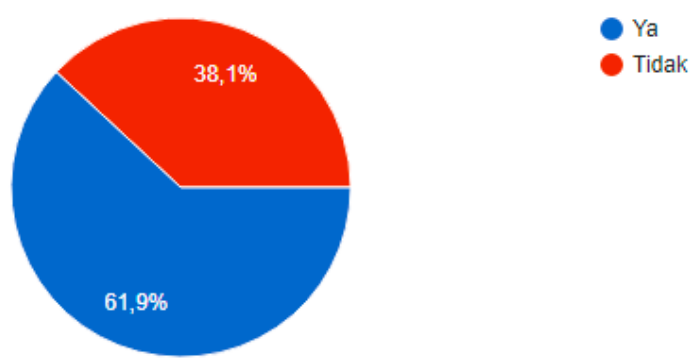

Gambar 6. Ketertarikan orang tua dalam penggunaan video pembelajaran

Berdasarkan hasil observasi, orang tua menyatakan bahwa anak usia 4-6 tahun lebih tertarik jika pembelajaran menggunakan media video pembelajaran dibandingkan yang tidak menggunakan. Dengan dibuktikan jawaban respondon sebanyak $61.9 \%$ menyatakan tertarik 
sedangkan sebanyak $38.1 \%$ menyatakan tidak tertarik terhadap video pembelajaran.
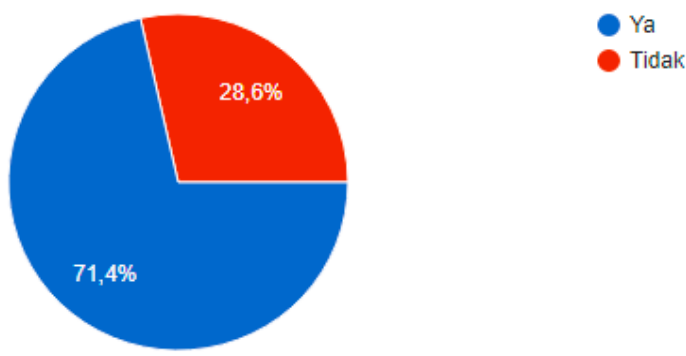

Gambar 7. Ketertarikan anak dalam penggunaan video pembelajaran

Namun, dalam pertanyaan selanjutnya mengenai rasa bosan yang dirasakan anak terhadap penggunaan video pembelajaran diperoleh informasi sebanyak $71.4 \%$ orang tua mengatakan bahwa anak merasa cepat bosan dan sebanyak $28.6 \%$ anak tidak cepat bosan menggunakan media ini. Telah dipaparkan oleh Kurniawaty dalam penelitiannya yang dikutip dari Fahri (2020) dinyatakan bahwa penggunaan media pembelajaran yang menggunakan video itu diminati oleh anak.

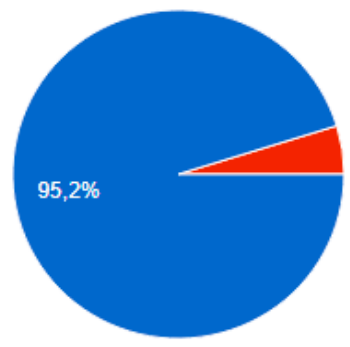

$$
\begin{aligned}
& \text { Ya } \\
& \text { Tidak }
\end{aligned}
$$

Gambar 8. Instruksi dalam video pembelajaran memudahkan anak

Anak-anak ternyata mudah mengikuti hal-hal sederhana yang dicontohkan dalam video pembelajaran seperti, gerakan-gerakan karena responden sebanyak 95.2\% mengatakan bahwa anak mudah mengikuti hal tersebut.

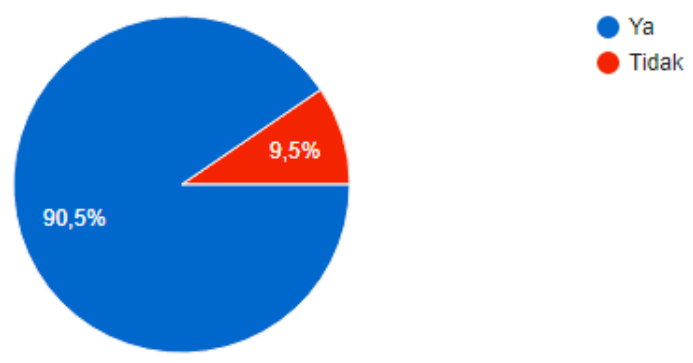

Gambar 9. Respon motorik kasar anak pada saat menonton video pembelajaran

Orang tua menyatakan bahwa tetap ada perkembangan motorik kasar yang dicapai anak meskipun dengan menonton video pembelajaran dengan jawaban mengatakan "Ya" sebanyak $90.5 \%$ dan sisanya sebanyak $9.5 \%$ mengatakan bahwa tidak melihat adanya perkembangan motorik kasar pada anak usia 4-6 tahun yang dicapai dengan menonton video pembelajaran.

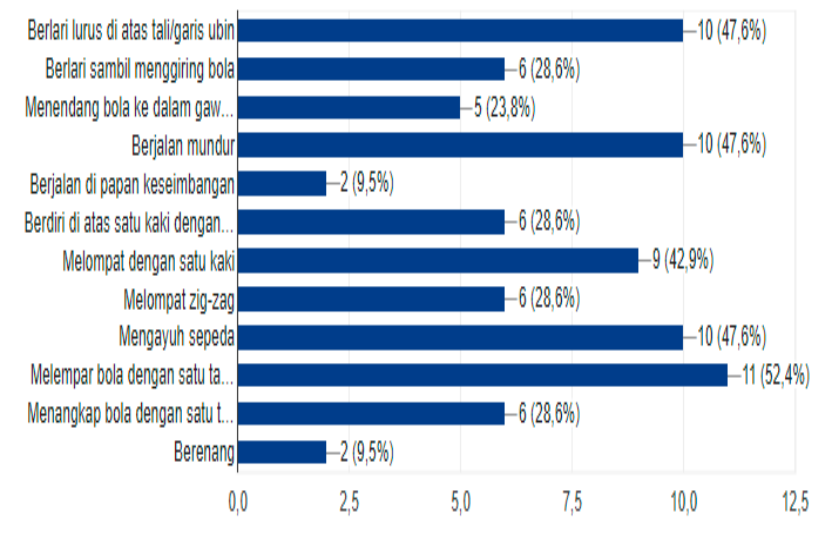

Gambar 10. Contoh kegiatan yang dilakukan anak setelah menonton video pembelajaran

Perkembangan motorik kasar yang banyak terlihat dari hasil responden mengatakan bahwa melempar bola dengan satu tangan sebesar 52.4\%, mengayuh sepeda, berjalan mundur, berlari lurus di atas tali atau garis ubin sebanyak $47.6 \%$, melompat dengan satu kaki sebanyak $42.9 \%$, menangkap bola dengan satu tangan, melompat 
zig-zag, berdiri di atas satu kaki dengan seimbang, berlari sambil menggiring bola sebanyak $28.6 \%$, menendang bola ke dalam gawang sebanyak $23.8 \%$, dan berjalan di papan keseimbangan beserta dengan berenang sebanyak $9.5 \%$.

Menurut Bungsu dan Saridewi (2021) memaparkan beberapa komponen yang ada pada aspek perkembangan motorik kasar, yaitu:

a. Lokomotor: bentuk kegiatan Berlari lurus di atas tali/garis ubin, berlari sambil menggiring bola, berjalan mundur, berjalan di atas papan keseimbangan, melompat dengan satu kaki, melompat zig-zag

b. Non-lokomotor: Menodorong, menarik, menekuk, menegang, meloncat ditempat, memutar, menggeleng, mengangguk, membungkuk, dan mengayunkan tangan

c. Manipulatif: Memukul, melempar bola dengan satu tangan, menendang bola sambil menggiringnya, memantulkan, memutar tali, dan menangkap objek

Menurut hasil tersebut bahwa video pembelajaran belum maksimal bisa mengembangkan perkembangan motorik kasar anak usia 4-6 tahun dikarenakan satu komponen dalam lokomotor belum tercapai yaitu memanjat. Lalu, dalam kemampuan non-lokomotor masih banyak belum terlihat seperti, mendorong, menarik, menekuk, menegang, melompat ditempat, memutar, menggeleng, mengangguk, membungkuk, dan mengayunkan tangan. Pada kemampuan manipulatif pun beberapa komponen belum terlihat seperti, gerakan memukul, memantulkan, memutar tali, dan menangkap objek. Terlihat bahwa dalam kemampuan perkembangan motorik kasar anak usia 4-6 tahun masih banyak sekali indikator yang belum tercapai oleh anak ketika menggunakan pembelajaran melalui video pembelajaran.
Tentunya hal ini bukan saja hanya kewajiban pendidik untuk mengembangkannya, tetapi harus ada keterlibatannya pula dari orang tua. Keterlibatan tersebut bisa berupa mengupayakan pembelajaran di rumah tetap bisa mengembangkan motorik kasar anak dengan beberapa kegiatan yang bisa memicunya, seperti berolahraga, kegiatan permainan.

\section{SIMPULAN DAN SARAN}

Hasil penelitian menunjukkan bahwa gambaran video pembelajaran terhadap perkembangan motorik kasar anak usia 4-6 tahun di Kelurahan Bojong Menteng yaitu masih belum maksimal dikarenakan dalam beberapa jenis motorik kasar, komponennya belum terpenuhi semua. Jenis lokomotor yang belum tercapai yaitu gerakan memanjat, jenis non-lokomotor yang belum tercapai yaitu gerakan melompat ditempat, menekuk, menegang, mendorong, memutar, menggeleng, mengangguk, membungkuk, dan mengayunkan tangan, jenis manipulatif yang belum tercapai yaitu gerakan memukul, memantulkan, memutar tali, dan menangkap objek.

Saran bagi para pendidik perlu memperhatikan pada saat pembuatan video pembelajaran khususnya pada aspek motorik kasar anak yang meliputi (lokomotor anak, non-lokomotor anak, dan gerak manipulatif). Hal tersebut sebaiknya juga perlu memperhatikan tahapan perkembangan yang perlu dipenuhi anak pada setiap jenjang usianya.

\section{DAFTAR PUSTAKA}

Andini, D. P., Marlinah, Nurchahyani, Apriyanti, S., \& Yuliantina, I. (2021). Peningkatan motorik kasar melalui pembelajaran daring berbasis whats app. Efektor, 8(1), 89-97 DOI:https://doi.org/10.29407/e.v8i1.15880

Bungsu, P., \& Saridewi. (2021). Dampak pembelajaran dalam jaringan (daring) 
terhadap perkembangan motorik kasar anak usia dini. Jurnal Pendidikan, 5(1), 11-20.

Farida, A. (2016). Urgensi perkembangan motorik kasar pada perkembangan anak usia dini. Jurnal Raudhah, 4(2), 2338-2163. http://dx.doi.org/10.30829/raudhah.v4i2.52

Fitri, A., \& Ismet, S. (2019). Kegiatan pengembangan motorik kasar. Pedagogi: Jurnal Pendidikan Anak Usia Dini, 5(1). DOI:https://dx.doi.org/10.30651/pedagogi.v5i 1.2517

Kurniawaty, L., Ristiani, I., Apriliani, S. R., Gustini, G., Sa'diyah, H. M., \& Rosdiana, D. (2021). Penggunaan video pembelajaran bagi anak usia dini dalam pembelajaran daring. Jurnal Pengabdian Kepada Masyarakat, 11(1).

DOI:https://dx.doi.org/10.30999/jpkm.v1i1.12 95

Nadhira, S. (2020). Gambaran perkembangan motorik anak usia dini yang menggunakan gawai.
Putra, A. Y. (2020). Strategi pembelajaran motorik kasar pada anak usia dini era pandemi covid-19. Jurnal ilmiah tumbuh kembang, 5(4), 159-166.

DOI:https://doi.org/10.14421/jga.2020.54-03

Soetjiningsih, C. H. (2018). Perkembangan anak. Depok: Prenadamedia group.

Sola, M. E., Oka, G. P., \& Ngura, E. T. (2021). Pengembangan media video pembelajaran gerak dan tari kearifan lokal ngada untuk melatih kemampuan motorik kasar pada anak usia 5-6 tahun di TKK ST. Skolastika Mataia. Jurnal Citra Pendidikan, 1, 99-114.

Sugiyono. (2016). Metode penelitian kuantitatif, kualitatif dan $r \& d$. Bandung: PT Alfabet.

Taib, B., \& Mahmudi, N. (2021). Analisis kompetensi guru paud dalam membuat media video pembelajaran. Jurnal Obsesi: Jurnal Pendidikan Anak Usia Dini, 6(3) 1799-1810. DOI:10.31004/obsesi.v6i3.1842 